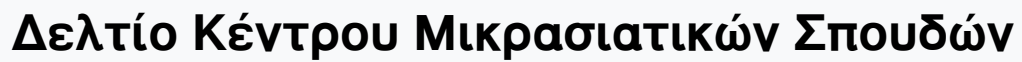

Tón. 13 (1999)

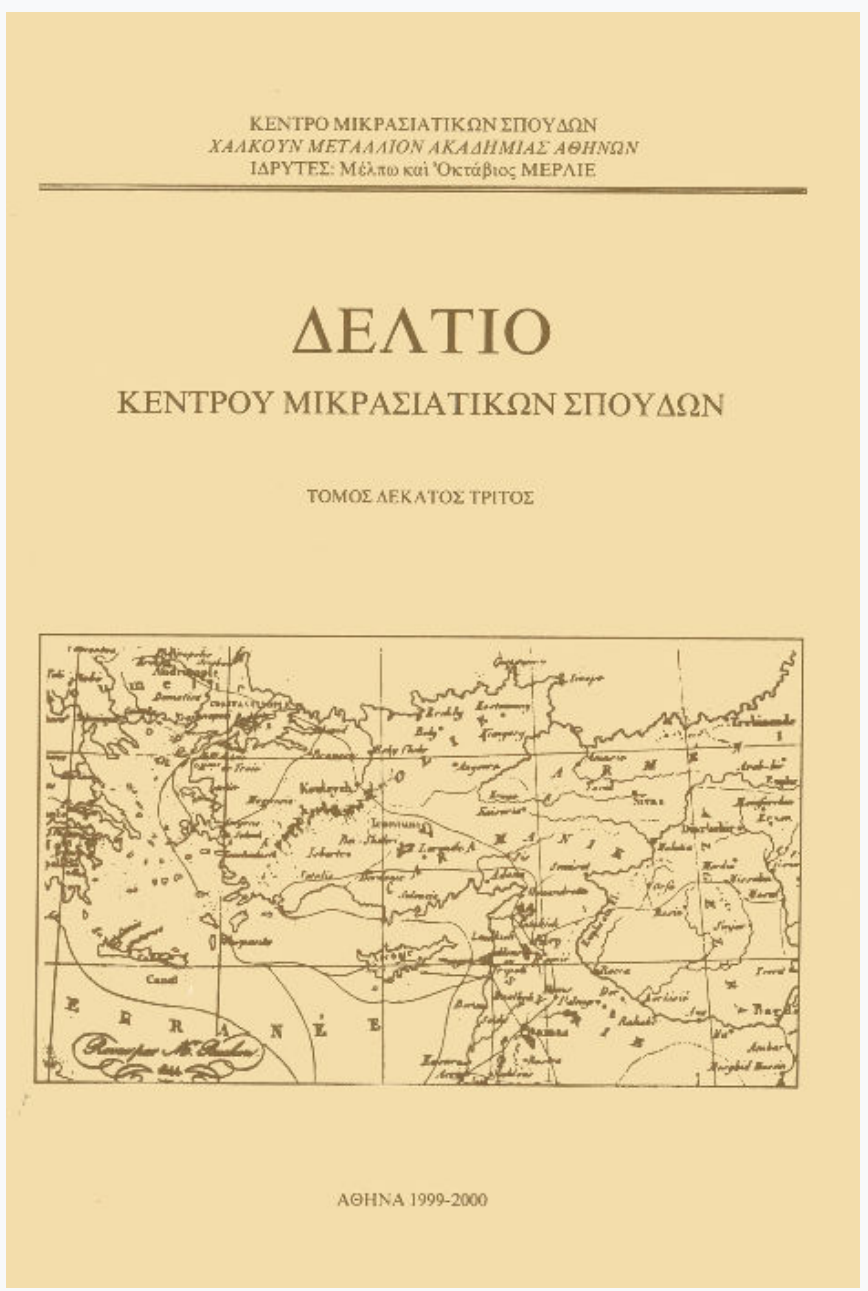

\section{Afterthoughts of another orthodox historian on the same subject}

Andrei Pippidi

doi: $10.12681 /$ deltiokms.154

\section{Copyright (c) 2015, Andrei Pippidi}

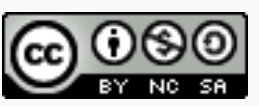

Aঠ¿ıı Xpńбnৎ Creative Commons Attribution-NonCommercial-ShareAlike 4.0.

\section{Bıß入ıорафıкń avaџорá:}

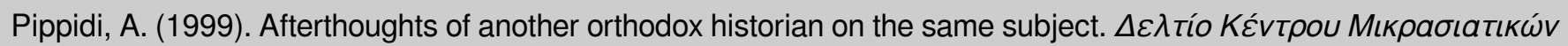

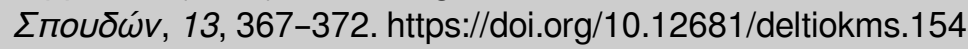




\section{ANDREI PIPPIDI}

\section{AFTERTHOUGHTS OF ANOTHER ORTHODOX HISTORIAN ON THE SAME SUBJECT}

It's a sad story that Pofessor Pavlowitch is telling us. He does it without any prejudice, with a lucid detachment which is rare nowadays, especially when this kind of objectivity is not flawed by skepticism. Let me try to add a few unsystematic remarks resulting from a parallel experience and confirming the pattern thus drawn.

It is generally acknowledged that in South-Eastern Europe the relationship between the Church and the state was influenced by two precedents. The first, remote as it is, but still very present through the ritual and the mental background, is the symphonia (agreement) which united the interests of emperor and patriarch - an interpenetration which so distributed the authority that neither was political life immune from religion, nor were ecclesiastical affairs autonomous. The second stage came after the fall of Constantinople, when the millet system of self-government under religious leaders was created and later extended from the Greeks, Slavs and Romanians, who formed together the group of Orthodox Christians, to the Armenians, the Jews and other major non-Muslim minorites. The allegation that a separation of the Church from the state was then achieved can be supported by historical evidence, but only in a sense which was revived five centuries later during the period of Communist rule. This means control and tutelage exerted by rulers who were in fact the ideological enemy, though it almost never was declared as an overt conflict.

The only exception to this situation were the twin principalities of Wallachia 
and Moldavia, that were granted autonomy and where the Byzantine model was preserved. Under the nominal authority of the patriarch of Constantinople, who had become a prisoner of the Turks, the two Romanian Churches recognized as their protector and censor an Orthodox prince who was himself obeying to the sultan. In this case, the religious life of the Romanians was not harrassed by the same constraints which challenged the Balkan Christians, and they even supported the Christian East through generous donations to many sanctuaries (Mt. Athos, Jerusalem, Sinai etc.) and through the printing of religious books (in Church Slavonic and later in Greek).

They also resisted several attempts to convert them to Catholicism (or, some other times, to Protestantism). This stubborn defence of their Orthodoxy even estranged them for a while from that Latin culture which would have brought them into line with the other nations speaking a Romance language, but which they rejected as an instrument of the Western missionaries who threatened their traditional identity. In the third of the Romanian provinces, Transylvania, Orthodoxy was never one of the official confessions, but only tolerated; an inferior status corresponding to the social discrimination against the Romanians in that Hungarian-ruled principality.

Henceforth, it can be said that in South-Eastern Europe religion was a barrier against assimilation (in the Balkan peninsula, it helped to keep alive amidst the Christians the memories of their past independence in the same way that it acted everywhere for the Jews). On the other hand, one must remember that the Church was hostile to a secular current like nationalism - a case which has been abundantly argued with Greek examples. And it is true that the advent of nationalism had a disruptive impact on the common bond which had, until then, associated the Orthodox Christians. A proof can be found in the aggressive policy of the Serbian Church in the Banat, where the Illyric nation had asked for supremacy in "dogmaticis et pure spiritualibus», a request granted by the imperial government in 1779 , though the Romanian population of that region was twice more numerous.

Professor Pavlowitch is right to suggest that the Russian model, though it lured the Balkan Christians through its neo-Byzantine pageantry and through the hope of freedom that it offered, contributed to enroll the Church in the service of state. The Lutheran influence, deeply rooted, of course, in the Petrine reforms, was also introduced into King Otto's Greece. The secularization of ecclesiastical lands began by a measure of the Greek government and was imitated, thirty years later, by Alexander Cuza, the first ruler of the United Romanian Principalitites, causing 
considerable anger in the Greek clergy who benefited from those estates (question of the dedicated monasteries [ $\mu \varepsilon \tau \delta^{\prime} \chi\llcorner\alpha], 1863$ ). It was then that a law forbade the use in church of other languages than Romanian, the final term of a process which had started in the 17th century with the translation of liturgical books.

Balkan disunity produced national Churches, but this enterprise had not been initiated by the clergy: it was coming from politicians, who in most cases were anti-clerical or belonged to the freemasonry. It was quite obvious in the case of the Bulgarians, who in the space of only one generation had progressed from the reading of Fénelon to the more modern ideas of Darwin. In 1831 the Ecumenical Patriarchate recognized the autonomy of the Serbian Church and in 1870 the Bulgarians obtained a firman from the sultan establishing a Church independent from Constantinople.

For the Romanians, the process was a more complex one. In Transylvania, since 1700 , the Romanian population was religiously divided in two: Orthodox and Greek Catholic. Uniatism was encouraged by the Habsburgs who had recently acquired the province and who felt it necessary to create a rival pole of attraction in front of the Orthodox whose loyalty to the Wallachian Church, across the Carpathians, made them suspect from the political point of view. During the 18th century, the Romanian intelligentsia developed a local cultural style which was characteristic for the Uniate circles: at its core was the discovery of Latin origins, a scholarly argument for claiming equality of status with the other four accepted (privileged) denominations: Roman Catholicism, Lutheranism, Calvinism, Unitarianism. The Orthodox Church of Transylvania lagged behind in an inferior position until the Toleration edict of Joseph II (1781). Meanwhile, in the Romanian provinces left under Turkish domination and expecting their liberation, planning even their future as satellite countries in the shadow of the Third Rome, the Phanariot princes confined the Church to the administration of schools and charitable institutions. Its large endowments were increasingly exploited by Greek monks and Cuza's reform took away these resources which might have been employed for social assistance. With the Western model of modernity spreading, this laicization from above was already starting to dissolve the traditional framework of daily life. This fracture deprived Romanian society of most of its medieval heritage. By the 20th century, the Orthodox Church, unable to inspire or to control the masses any more, was backward-looking, yet careful to pay Caesar's due.

In the new Romania, much expanded in population and territory after the First World War, opposition between the Uniate and Orthodox Churches played 
a large role. The growth of Romanian nationalism had to conciliate the two divergent traditions, each of them embodying a different cultural identity, Mitteleuropäisch and Balkan. Miron Christea, the Transylvanian prelate who was elected as the first patriarch of the autocephalous Church of Romania, was a steadfast Orthodox. The diary of his close friend, the poet and chauvinist politician Octavian Goga, as well as his own secret memoirs which have been published only last year, show the Patriarch's mundane and ambitious sides. He assumed the high office of heading the three-men regency that ruled the country in the name of young King Michael and in 1938-1939, under the personal dictatorship of King Carol II, he accepted to be a decorative Prime Minister, endorsing the suppression of political parties. In such conditions, it's hardly surprising that he introduced into the constitution the provision that the Orthodox Church is dominant in Romania. National was then an attribute still shared by the Orthodox with the Greek Catholics. Through the writings of such thinkers as Nichiphor Crainic, Simion Mehedinti and Nae Ionescu, all of them German-educated, a radical national ideology was elaborated linking Romanian national character with Orthodoxy. Crainic provided the theory of autochthonous state for the antisemitic leanings of the royal dictatorship, and Ionescu went as far as denying the Romanianness of the Uniates, not to speak about the Jews, who were unredeemably fated to suffer for the sin of Judas.

I cannot present here a report on the religious situation in Romania under the Communist regimes (there were two of them: the Soviet-type rule, followed by the extreme nationalistic version which collapsed in 1989). An effort should be made to collect data and to determine the effects of these two dictatorships on religious life.

The Greek Catholic Church was suppressed in 1948, under the pretext of restoring the unity of the nation: the members of the Uniate clergy either adhered to Roman Catholicism, or went undergound. Their bishops died in prison or were released only in extremis. Whole villages deprived of their priests were unable to resist and were absorbed by the Orthodox majority. Therefore, since 1990 it has proved difficult to revive the Uniate Church, now reduced to $1 \%$ of the total population. Repression ravaged also the ranks of the Orthodox clergy: interdictions to officiate, imprisonments, while many monks and nuns were forcibly sent to resume lay life. For about forty years people were not allowed to practice their religion outside the control of the state. Atheism was taught in schools and universities, or even through the ideological indoctrination of adult employees, while religious instruction was hindered. Clergy were required to 
swear oaths of loyalty or to make official declarations in support of the Party.

This subservient position of the Church was taken as target of many criticisms after 1990, as was the intolerant attitude opposed to the attempts to restore Uniatism. Officially, the Greek Catholics have been granted their rights, but the question of Church properties is still pending in court with various and always protracted results. A curious episode of this conflict was highlighted by Katherine Verdery, in her book The Political Life of Dead Bodies (Columbia University Press, 1999), where the American anthropologist describes the 1997 reburial of Bishop Inochentie Micu in his natal Transylvania after an exile of two centuries. In former Bessarabia, which has obtained independence under the name of Moldova, the Orthodox Church is split up by a schism of political origin, between Moscow and Bucharest, the rival centres of influence in the region.

To the loss of prestige and credibility, the Orthodox Church is reacting in several ways. Its strong opposition to the evangelistic movements and the distrust manifested to the Catholic Church are not merely reflexes of conservatism, but they mean to make clear that the Orthodox Patriarchate claims the position of an arbiter in specifically religious problems, as well as in politics. The debate over the title of National Church has shown who is becoming the defender of national identity. The governments of the early $1990 \mathrm{~s}$, being in a crisis of legitimacy, played the card of the Orthodox hierarchy and ostentatiously adopted ecclesiastical rituals whenever they wanted to impress the masses, an attitude which was wholeheartedly carried on by their Christian-Democrat successors. Plans of bulding a new Cathedral, of a huge size, in Bucharest, and another in Cluj, where it is clearly intended to show up in front of the religious and ethnic rivals, are concomitant with the canonization of thirteen new saints, a patriotic strategy which had been arleady implemented after the 1948 unification of Churches. A great number of Orthodox monasteries are being founded throughout the country, sometimes on the ruins of old religious settlements.

The visit of Pope John Paul II to Bucharest, which had been for quite a long time the object of diplomatic negotiations, was not the occasion of a historic Orthodox-Catholic reconciliation, but strengthened the position of Patriarch Teoctist as a partner of the Romanian government. However, some voices in the Orthodox hierarchy have outspokenly expressed their concern about the present administration, as too lenient and too open to the West. The warning that the votes of the clergy and of their rural flock might help to bring the opposition into power certainly sounded alarming to the ears of Romania's political leaders. 
No competition with other Churches represents a real difficulty for the Orthodox community which, after all, constitutes the overwhelming majority ( $86 \%$ of the total population). The real problem is to find the delicate balance between a reasonable and sincere respect for tradition and a Christian modesty which should make us ready to learn from alien wisdom. As longs as village boys will go to seminary to become priests -as they used, before 1989, to vest a policeman's uniform to escape poverty- we shall not have that educated and dignified clergy that is an indispensable condition to the straightening of Romanian Orthodoxy. A Church confiscated by nationalism and underevaluating its social duties, this is, I'm afraid, what indicates the converging surveys at the present turning point. And finding myself in full agreement with Professor Pavlowitch is not enough of a consolation. 